\title{
Person Deixis and Point of View in English-Arabic Fiction Translation: A Trend towards Repositioning the Narrator, Characters and Readers
}

https://doi.org/10.33806/ijaes2000.19.2.2

\author{
Othman Abualadas \\ The University of Jordan-Aqaba, Jordan
}

\begin{abstract}
This paper reports on deictic shifts in fiction translation. It examines the shift in person deixis in two Arabic translations of Charlotte Brontë's Jane Eyre. The goal is to trace how the process of translation may change the narratorial point of view of the original, a territory in English-Arabic fiction translation that is still largely unexplored from an empirical perspective. The study presents a replicable descriptive model for use with larger corpora to help in the description of the "norms" of English-Arabic fiction translation (Toury 2012). The results point to a tendency to add rather than omit person deictics via translation, with more deictically-marked narrative, more involved narrator and characters, more vivid and shared context, more context construction by reader and more dynamic interaction with the text. The results suggest that there is an increased level of enunciation of the narrator and characters that can increase both the main narrator's subjectivity and the reader's ethical and emotional involvement with her. The addition of person deictics reflects a systemic tendency to "interpret" and "explicitate" the source text (Blum-Kulka 2000), and shows textual evidence of the translator's intolerance of ambiguity and/or their systematic avoidance of taking a "communicative risk" (Pym 2005).
\end{abstract}

Keywords: deictic shifts, English-Arabic fiction translation, person deixis, point of view, translation norms

\section{Introduction}

This paper aims at studying shifts in person deictic items and their effect on the narratological structure of the original. Though some previous studies have made some claims about the translation of deictic expressions from English to Arabic, these claims tend to be prescriptive in nature and have largely neglected the systematic shifts in the deictic features of the original (e.g. Aziz 1993; Emery 2004; Hassan 2011; Baker 2011). Systematic shifts in person deixis and their effect on the point of view of the original have been largely ignored in the study of English-Arabic fiction translation. Most of the existing literature in this area has concentrated on obligatory shifts arising from structural differences between English and Arabic (see Section 2.3) and the way to achieve equivalence, but has overlooked optional shifts that may affect some original narratological characteristics, such as narratorial participation and narratorial objectivity. The present study hopes to fill these gaps in the literature. 


\section{Related literature}

\subsection{Deixis: Definitions and types}

For those who treat language as a generative system for objectively describing the world, deixis is a big black fly in the ointment. Deixis introduces subjective, attentional, intentional and, of course, contextdependent properties into natural languages (Levinson 2006: 97).

Deixis involves pointing to elements in the outside world. It is those features of language that relate linguistic expressions to the extra-linguistic environment to convey a meaning. It is the orientational aspects of language that function to situate utterances in relation to the viewpoints of the speaker; the demonstratives "Those" and "that" in "Those books over that shelf are mine" refer to physical orientation in language by pointing to the position of the speaker in relation to the other entities stated in the utterance (Simpson 2005: 12). The literature distinguishes between several types of deixis, such as time deixis, place deixis and person deixis (Levinson 1983). Time deixis involves the different times referred to in the speech act, which can been coded in the different tenses (e.g. past and present) and the various temporal adverbs like "now" and "then". Place deixis encodes the location of the speaker in the physical space at the utterance time, which can be expressed by place adverbs like "here" and "there" and demonstratives such as "this" and "that".

Person deixis, which is the main focus of the present study, involves the roles of individuals in the speech event, which are most obviously manifested by pronominal systems and inflectional marking. In English these can involvepersonal and possessivepronouns like"he", "she", "her", "my" and "mine". Levinson (1983: 68-69; 2006: 112) uses two characteristics to describe person deixis: speaker inclusion [S] and addressee inclusion [A]: first-person encodes the participant role with speaker inclusion $[+\mathrm{S}]$, second-person encodes the role with addressee inclusion $[+\mathrm{A},-\mathrm{S}]$, while third person encodes the exclusion of both speaker and addressee $[-\mathrm{S},-\mathrm{A}]$.

\subsection{Deixis in fiction: Deictic shifts and point of view}

The typical or unmarked deicticcenter to which deictic elements are anchored is the speaker's current temporal and spatial locus. But the anchor point maybe shifted to other participants in the speech event. In a fictional text, the anchor point may shift from the author to the narrator or characters and this is actually what allows a reader to get inside a fictional text by adopting a cognitive stance with a mentally-constructed text world (Stockwell 2002: 46-47).Since deictic elements are very context-dependent, reading a fictional text may automatically involve a process of context-construction so that a reader can follow the deictic center of these deictic elements. This process is dynamic and keeps shifting, and it is what makes reading a creative process, where a reader keeps creating a cognitively negotiable text-world (Stockwell 2002: 46). This tracking of who, where and when is also a part of the information that a reader needs to constantly retain to make necessary coherence inferences(Toolan 2016: 160). 
Besides bridging words and the world, deixis helps establish the point of view (or focalization) of a narrative text (Uspensky 1973;Fowler 1996). Point of view in narrative fiction is the perspective from which a story is told. It involves the various techniques which the writer adopts to allow the reader to hear and see the story events and the basic viewing positions adopted in the story. Deixis, among other linguistic elements, situates the speaking voice in temporal and physical space, while in the text, the narrator establishes a deictic center(an "origo") around which entities in the story are positioned in relation to their relative distance or proximity to the narrator (Simpson 2004: 28).

Person deixis is central to the characterization of the narrative voices or narrative modes in fictional discourse (Fowler 1996: 169-182; Black 2006: 5562).In a first-person narration, the writer tells the story using first-person deixis like "I" and "we", such as in Charlotte Brontë's Jane Eyre. Such an internal narrative mode allows the reader to see and hear through the main narrator's eyes and ears. It is often characterized as being limited to the narrators' subjective perception of reality, revealing their personal feelings and subjective evaluations of the other participating characters. A third-person narrative relates the story using third-person deixis like "he", "she" or "they", such as in Jane Austen's Pride and Prejudice. This allows for an external narrative mode where the narrator can be a non-participating observer of the events and characters of the story, allowing for a more objective and unbiased point of view.

\subsection{Deixis in translation studies}

A number of studies have emphasized the importance of deixisin translation studies (e.g.Mason and Şerban 2003; Goethals 2009).Richardson (1998: 125) points out that deixis, a side of language that is sensitive to context, may need to be adapted to the perspective of the target audience: "the deictic perspective which pervades the TL text must be structured in such a way that it is deemed coherent by the TL reader" (see also Morini 2013).Fawcett (2003: 95-96) highlights the structural differences between languages in the use or form of deixis (see Baker 2011: 193-196). Arabic language for instance has the same set of personal deixis as English, i.e. first-person, second-person and third-person. However, unlike English, Arabic person deixis can occur as a free morpheme, like "huwa" (he) and "Pantum" (you) or bound; as asuffix attached to verbs and nouns, like the second person possessive suffix "uk" in "baytuk" (your house) (Badawi, Carter and Gully 2016: 50-54). Unlike English, Arabic has dual personal pronouns, and also has masculine and feminine versions of the second and third person plural pronouns. When translating from English into Arabic, such system differences result in a shift that leads to a higher grammatical explicitness in translation (Klaudy 2009). Such translation shifts are termed optional or nonobligatory shifts (Toury 2012), and since they do not originate form a translator's stylistic choice or translation strategy, they are not often considered important in translation studies.

Other studies have explored the systematic shifts in deixisin translated narrative fiction and their influence on the perspective adopted in the original. 
Mason and Şerban (2003) examine the shifts in time and place deixis in a number of Romanian-English translated novels. The findings point to a tendency to change proximal deictic elements like "here" and "now" into distals like "there" and "then", with the overall effect of distancing the target readers, evoking less dynamic interaction with text on their part and allowing for more objective point of view in comparison with the original narrative.

Bosseaux (2007) uses a computer-based model to explore shifts in the deictic "I", "here" and "now" in French translations of an English novel, in an attempt to trace the narratological aspects pertinent to the translated narratives. The findings indicate that translations retain fewer deictic expressions and focal points than the original narrative. This also points to a tendency to losing the deictic anchorage of deixis via translation. Her study also suggests that since the deictic expressions of the original allow the narrator to enunciate his/her position while speaking, their omission in translation should mean a narrative with a less emphasized or involved narrator.

Abualadas (2015, see also Abualadas2018) examines shifts in time and place deixis in three Arabic translations of Wuthering Heights. The results point to a translated narrative that is more deictically-marked than its original and a trend to emphasize the enunciation of the main narrator's location in time and space. The study also examines the shifts in person deixis. The results show a tendency to omit rather than add person deixis, with the effect of emphasizing the main narrator's role more than the other characters by replacing forms anchored to characters with other forms anchored to the main narrator. But one methodological problem of the study is that it has ignored person deictics that are added by the process of explicitation, making what is implicit in the source text explicit in the target text (Vinay and Darbelnet 1995: 342), such as when translating "the picture is nice" into "the picture you drew is nice", which adds the person deictic "you". The study has focused only on the addition of person deictics that occurs as a result of (i) replacing a definite/indefinite article or a demonstrative with a person deictic (such as when translating "a/the/this horse" into "his horse"), and (ii) changing from passive to active voice in translation (such as when translating "the house was evacuated" into "we evacuated the house").

Goethals and De Wilde (2009), in a Dutch-Spanish translated novel, find that these translational deictic shifts are infrequent and unsystematic and therefore may not be related to an intentional translational choice. Goethals and De Wilde point out that that these shifts may be better seen as "traces of the translator's cognitive deictic center shift, i.e. the interpreter's effort of adopting the vantage point of the narrating voice(s) in the text" (2009: 791).

\section{The source and target texts}

The corpus used in the present study is the Victorian novel Jane Eyre by Charlotte Brontë(1847) and two Arabic translations made by two native Arabic speaker translators: Hilmi: Mu:ra:d (1998) and Mu:ni:r Bcalbaki: (2006). The two translators are prominent figures in the field of English-Arabic literary translation 
and have translated a significant number of classic English novels into Arabic. They are considered among the most important contributors to the Arabic translated literature, and therefore the study hopes to contribute to the description of their translational style (see Munday 2008). Many of their translations are taught in many schools in the Arab World. Hilmi:Mu:ra:d was the founder and editor of "Kita:bi:" (My Book), a prominent book series published by "da:r Al$\mathrm{ma}^{\mathrm{c}} \mathrm{a}$ :rif" in Cairo and which is specialized in the world literature classics translated into Arabic. Mu:ni:r B ${ }^{c}$ albaki: was the founder of "da:r al-ilmli-almala:i:i:n" a leading Lebanese publishing house of Arabic books and translated literature.

The original novel is divided into thirty-eight chapters, but in order to give a contextualized analysis of the deictic features and narrative point of view, the analysis of the whole novel will go beyond the scope of this study. The study selects the first eighteen chapters of the story, which amount to around 78,000 words and their two Arabic translations. The primary goal is not to give an exhaustive analysis of all person deixis used in the novel, but to provide hypotheses that can be tested on different and/or larger corporato help describe the features of English-Arabic fiction translation.

The novel is a first-person narrative told from the point of view of its protagonist, Jane Eyre. The novel is set in the countryside of North England in the early decades of the nineteenth century. It narrates the story of Jane Eyre, a poor orphan girl who is abused and challenged by her aunt and cousins. But her determination and search for identity make her face oppression and become stronger and independent, and eventually marry the person she loves, Edward Rochester.

Charlotte Brontë makes use of an old convention in English fictional writing; the story is allegedly an autobiography written by a real person called Jane Eyre and edited by Currer Bell, the pseudonym used by Charlotte Brontë. The readers are sometimes directly addressed with the word "reader" (Napierkowski 1998: 171). Charlotte Brontë's narrative firstly builds the narrative authority of Jane Eyre and strengthens her character, which then convinces the readers of the narrator's reliability by virtue of the combination of integrity, determination, and vulnerability which her character reveals (Bloom 2007: 19).Her presentation of her character in the first four chapters has always been distanced and modest (Bloom 2007: 19).

The story also uses the bildungsroman form, where the first-person narrative charts Jane Eyre's development from an isolated orphan to an independent and strongwoman (Jacobson 2000: 7). This engages the reader mentally with Jane's journey of moral and psychological development, where the reader works as accomplice in her story, actively reflecting and changing along with her character. Also, Jane Eyre sometimes looks more omniscient than a traditional first-person narrator; she talks about other characters; both their appearance and their internal thoughts, and sometimes she gives certain observations and views on life, those which look as if they belong to the writer (Napierkowski 1998: 171-172). But this does not mean that the narrator is always 
omniscient; sometimes Jane Eyre does not expose certain information until the story comes to the point when she is aware of it, such as when she lives with Mary, Diana and St. John Rivers for a while before she comes to know that these three are her cousins.

\section{Methodology}

To analyze person deictic shifts in translation, the study adopts a manual approach that compares "what is (potentially) done by the original author in or by the text" and "what is (potentially) done in the translation as a response to the original" (Hickey 1998: 4; see Şerban 2013: 15-21). The study will identify the person deictic items used in the original narrative and then analyze how they are translated, tracing any kind of variation in their translation and its effect in the deictic structure and viewpoints of the original. The study will categorize and quantify the shifts and then will attempt to describe the translational phenomena that the trends of shift suggest.

\section{Analysis of the translations}

The study has analyzed the two Arabic translations and looked for any shift in the use of the person deixis that may suggest an alteration to the viewpoints adopted in the original narrative. The study has found 354instances of shift. The shifts are brought about due to two main factors: (1) adding new person deictic items and (2) omitting person deictic items.

The addition of new deicticsis caused by three translational processes. The first process is the insertion of a new person deictic item in the translation, such as when translating "an answer" into "an answer from him" or "That is the house" into "That is the house where I met her", which involves the addition of the deictic items "him" "I" and "her". This process involves what is often called lexical addition, the insertion of new meaningful units in the target text (Klaudy and Károly 2005: 15). The study will refer to this group of shifts as shifts resulting from lexical additions. The second process is the substitution of a definite or indefinite article with person deictic item (e.g. when translating "the neighbours" as "our neighbours"), and substituting a demonstrative (e.g. "this, "that") with a person deictic item (e.g. when translating "this village" as "our village"). This group of shifts will be referred to as shifts resulting from lexical substitution. The third process is the change from passive into active voice in translation, such as when translating "the decision was made" as "I made the decision". This last group of shifts will be referred to as shifts resulting from voice change. It is worth mentioning that the three categories may overlap; one may for instance argue that voice change may also involve lexical addition. The study does not actually seek to give categories with clear-cut boundaries, but rather to use categories that help explain the shift and provide grounds on which hypotheses can be formulated.

On the other hand, omission shifts are brought about mainly by the substitution of a person deictic item with a demonstrative or a definite or indefinite article (e.g. when translating "my situation" as "that situation" or "the 
situation"). The occurrences of both addition and deletion of person deixis in the two translations are given in Table 1. The comparison shows that there is a strong tendency to add rather than omit person deictic items via translation. The occurrences of addition shifts as related to their triggers in translation are given in Table 2.

Table 1. Shifts in person deixis in the two translations

\begin{tabular}{|l|l|l|l|}
\hline Type of shift & Mu:ra:d & B $^{\text {albaki: }}$ & Total \\
\hline Adding person deictic items via translation & 125 & 188 & 313 \\
\hline Removing person deictic items via translation & 28 & 13 & 41 \\
\hline
\end{tabular}

Table 2. Additions of person deixis in the two translations

\begin{tabular}{|l|l|l|l|}
\hline Type of shift & Mu:ra:d & B $^{\text {calbaki: }}$ & Total \\
\hline Shifts resulting from lexical additions & 80 & 139 & 219 \\
\hline Shifts resulting from lexical substitutions & 30 & 37 & 67 \\
\hline Shifts resulting from voice change & 15 & 12 & 27 \\
\hline Total & 125 & 188 & 313 \\
\hline
\end{tabular}

\subsection{Shifts resulting from lexical additions}

As Table 2 shows, 219instances of person deixis addition occur as a result of lexical addition. These have involved the insertion in the target text of additional information that is not explicitly stated in the source text. Such additional information can be claimed to be implicit in the original text and is often apparent from the original context. This has often been referred to in translation as the “explicitation technique"(Séguinot 1988: 108; Vinay and Darbelnet 1995: 342).

The study claims that the lexical additions that result in person deixis addition reflect four translational behaviours. The first behaviour is the translator's attempt to interpret or help interpret the intended message of the original utterance. Below are some examples. Note that underling is used to indicate the part of the English text translated into Arabic. The Arabic text is transliterated using The Library of Congress Transliteration System.The English gloss of the Arabic translation is given to help non-Arabic readers to see the shift in translation. The Bold Type is used to indicate the shifted features.

In Example (1),Jane Eyre hears that Helen, her friend at Lowood School, is terribly sick and may die soon, so she sneaks to the room where Helen is staying to see her, hoping not to find her dead. In Example (2), Jane helps Mr. Rochester and then he asks her if she lives in Thornfield Hall, a house nearby.

1. ST:Indisposed to hesitate, and full of impatient impulses - soul and senses quivering with keen throes-I put it back and looked in. My eye sought Helen, and feared to find death. (Chapter 9)

TT: wa- ${ }^{\mathrm{c}}$ ayna:yatabhatha:ni ${ }^{\mathrm{c}}$ an hilin, khashyata Pan?ajiduha:mayi:tah (Mu:ra:d, Volume 1, p.165)

[Gloss: and my eyes were looking for Helen, fearing to find her dead] 
2. ST:"You live just below-do you mean at that house with the battlements?" pointing to Thornfield Hall, on which the moon cast a hoary gleam, bringing it out distinct and pale from the woods that, by contrast with the western sky, now seemed one mass of shadow.

"Yes, sir."

"Whose house is it?"

"Mr. Rochester's." (Chapter 12)

TT: ayatukhidmatin?uPadi:ha: li-sayidi: (Mu:ra:d, Volume 1, p.228)

[Gloss: What favor can I do to my master?]

In (1), the utterance "feared to find death" is interpreted in translation as "fearing to find her dead", referring to Jane's friend, Helen. In (2), the translator translates Jane's response "Yes, sir" as "What favour can I do to my master?", in which the translator seems also to be trying to interpret the original utterance. As can be seen in these two examples, the translator has made interpretations that have inserted the person deictics "her", "I" and "my", which do not exist in the original utterance. This suggests that the target utterances introduce an identification of more participant roles compared to the original.

The second behaviour the lexical additions reflect is the explicitation of the identity of the speaker and hearer in the original utterances. This has involved spelling out both who is speaking and whom the speech is addressed to in the event. In Example (3) below, Jane narrates a conversation between Mr. Rochester and his housekeeper Mrs. Fairfax. But as the translation shows, the translator adds the utterance "wa-qa:lamukha:tibanPiya:ha:" (He said to her), which clearly states the identity of the speaker and hearer. Although the identity of these speech participants can already be understood from the context, the translator opts for explicitation and helping the reader in following up with the narrator.

3. ST: He rang, and dispatched an invitation to Mrs. Fairfax, who soon arrived, knitting-basket in hand.

"Good evening, madam; I sent to you for a charitable purpose. I have forbidden Adele to talk to me about her presents, ..." (Chapter 14)

TT: wa-qa:lamukha:tiban?ya:ha:: masa:?u alkhayriya:sayi:dati:;laqadParsaltu fi:talabiki: li-gharadinkhayri: ( $\mathrm{B}^{\mathrm{c}}$ albaki:, p. 211)

[Gloss:He said to her: Good evening, my madam; I sent to you for a charitable purpose]

The third behavior the lexical additions reflect is the explicitation of spatial information in the source text. This has involved addition of new place deictic information anchored to the narrator and which has also involved insertion of new person deictics anchored to the narrator. See the following examples.

4. ST: "Is it her Mr. Bates has been to see?" "Yes." 
"And what does he say about her?"

“He says she'll not be here long."(Chapter: 9)

TT: huwayaqu:1Pinnamaqa:maha:baynana:lanyatu:1 (B'albaki:,p. 128)

[Gloss: He says that her stay between uswill not be long]

5. ST:"Miss Eyre, draw your chair still a little farther forward: you are yet too far back; I cannot see you without disturbing my position in this comfortable chair, ..." (Chapter 14)

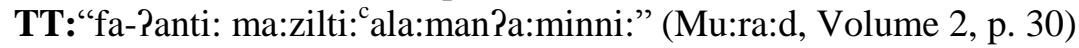

[Gloss:You are still away from me]

In (4), Jane asks the nurse about the health of her friend, Helen, and the nurse responds that the doctor, Mr. Bates, does not expect her to stay long in school because she may die soon. As the translation shows, the place deictic "here" which refers to Lowood, the charity school where Jane and Helen are staying, is translated as "between us". This translation explicitates certain presupposed deictic knowledge and at the same time adds the person deictic "us". In (5) Mr. Rochester sends to see Jane and his foster daughter, Adèle, and when he starts feeling comfortable with Jane, he asks her to sit close to him. Similarly, the place deictic element "back" is explicitated into "away from me", which inserts the person deictic "me". Such additions of person deictics suggest target utterances that enunciate the role or position of the speaker in the event while speaking.

The fourth behaviour the lexical additions reflect is the filling out of elliptical expressions via translation (Klaudy 2009: 104; seeAl-Khawalda 2002 for more details on ellipsis in both English and Arabic). This has resulted in new person deictics being inserted in the target text. In Example (6) below, Bessie, Jane's maid nurse, asks Jane if she has ever been in contact with her relatives on her father's side, and she replies "Never in my life". As the translation shows, the reproduction of the information omitted in Jane's short answer fills this elliptical expression and inserts person deictic elements ("I", "them") that are not explicitly stated in the original. Opting for a formal equivalent (Catford 1965),[Pabadan] (Never), could have conveyed the message and preserved the same level of implicitness, but the translator here opts for explicitation.

6. ST:“... There was something I wanted to ask you. Have you ever heard anything from your father's kinsfolk, the Eyres?" (Chapter 10)

"Never in my life."

TT: Pabadan lam Psma ${ }^{c c}$ anhum fi:haya:ti: ${ }^{c}$ ala:al-Pitla:q(Mu:ra:d, Volume 1, p.187)

[Gloss: I never ever heard about them in my life]

\subsection{Shifts resulting from lexical substitutions}

Table (2) also shows that there are 67cases of person deixis addition that occur as a result of replacing a definite/indefinite article or demonstrative with a person deictic element. In other words, this involves the substitution of a 
definite/indefinite phrase or demonstrative noun phrase with a possessive noun phrase. See the following two examples.

7. ST: The incident had occurred and was gone for me: it WAS an incident of no moment, no romance, no interest in a sense; yet it marked with change one single hour of a monotonous life. (Chapter 12)

TT:qadadkhalataghyi:i:ran ${ }^{c}$ ala:sa: ${ }^{c}$ atan min haya:ti:al-rati:bah (Mu:ra:d, Volume 1, p. 229)

[Gloss:It created a change in an hour of my monotonous life]

8. ST: Mr. Rochester had been absent upwards of a fortnight, when the post brought Mrs. Fairfax a letter.

"It is from the master," said she, ... (Chapter 17)

TT: Pinaha: min sayidina: ( $\mathrm{B}^{\mathrm{c}}$ albaki:,p. 262)

[Gloss:It is from our master]

In Example (7), Jane narrates that her incident with Mr. Rochester has created a change in her life, while in (8), Mrs. Fairfax tells Jane that the received letter is from the master, Mr. Rochester. As the translations in these two examples show, both the indefinite article " $a$ " and definite article "the" have been changed into personal pronouns ("my" and "our") anchored to the speaker of the utterance. In comparison with the source text, these shifts enunciate the speaker's relationship with the referents in the utterance and may also signal their participation in the events narrated.

\subsection{Shifts resulting from voice alternation}

Lastly, as Table (2) shows, 27cases of person deixis addition occur because of changing speech voice from passive into active while the Arabic equivalent grammatical construction is possible and can convey the same meaning. See the following two examples.

9. ST: The Sunday evening was spent in repeating, by heart, the Church Catechism, and the fifth, sixth, and seventh chapters of St. Matthew; and in listening to a long sermon, read by Miss Miller, ... (Chapter 7) TT: wa-Pumsiyatu al-ahadikuna:naqdi:ha: fi:tardi:diduru:sial-tacli:mialmasi:hi:yati ${ }^{c}$ an THahriqalbin, wa-tardi:dial-ishasa:hial-kha:misiwa-alsa:disiwa-al-sabi ${ }^{\mathrm{c} i}$ mina alPinji:l( $\mathrm{B}^{\mathrm{c}}$ albaki:, p.97)

[Gloss: and as to the Sunday evening, we were spending it in repeating Christianity lessons by heart, and in repeating chapter five, six and seven of the Bible]

10. ST:"Your directions shall be attended to, sir," said Miss Temple. (Chapter 7)

TT:fa-qa:latmistambil

"sa?a ${ }^{c}$ tani:bi-tawji:hatikaya:sayidi:

(Mu:ra:d,Volume 1, p.131) 
[Gloss: Miss Temple said: "I will take care of your directions, my lord]

In Example (9), Jane talks about how she and her colleagues used to spend their times at Lowood School and the hardship she was going through there. The original utterance uses the active tense, but the given translation voluntarily opts for the passive structure where the implied subject "we" is explicitly supplied and replaced the subject of the passive. This may shift attention from the patient (the receiver of the action) to the agent (doer of the action), putting emphasis on Jane's emotions and feelings in the event described. In (10), Mr. Brocklehurst gives Miss Temple some directions on how to manage the school, and she replies that "Your directions shall be attended to". Similarly, the translation shifts this passive construction into the active "I will take care of your directions", allowing for the projection of speaker in the translated utterance and her role in the original event.

\section{Discussion of results: Patterns and regularities 6.1Focalization}

The data in Table (1) and (2) indicate that there is a strong tendency in the two translations to add rather than omit person deixis via translating, suggesting a target text that is more deictically-anchored than the original; a target text that reveals more deictic knowledge than its original. This points to a target text with more focal points and with more emphasis being put on the participants' position and role in the narrative. This may not confirm (nor should it) the findings of Bosseaux (2007), which reveal that a translated narrative retains fewer deictic expressions and focal points than the original. It should also be stressed that the additions in the present study are not oriented towards only the main narrator, Jane, or only certain characters: they are anchored mostly to both the narrator and other characters of the story. The findings here may also contradict those of Abualadas (2015), which show both a tendency to omit rather than add person deixis and a tendency to emphasize the position of the main narrator more than that of other characters. It looks that explicitation shifts, which are ignored in Abualadas(2015), can significantly impact the final results.

\subsection{Involvement and empathy}

The study also finds that out of the 313person deictic elements added in the translations, 202 (about $64.5 \%$ of total additions) are either first-person like "I", "my" and "our" or second-person like "you" and "your". This may suggest a translation with more speaker and addressee inclusion $[+\mathrm{S},+\mathrm{A}]$ in the speech utterance compared to the original. This increased inclusion of both speaker and addressee via translation points to a more "interactive context" (Simpson 2004: 35 ) between the narrator and other speaking characters in the translated narrative. In "direct speech" mode (DS) (Leech and Short 2007: 258), this shift may create some physical or spatial closeness between speech participants in the narrative and help establish a more shared "deictic field" between them in the translated fictional dialogue (Richardson 1998: 131). This more frequent use of first-person and second-person deixis in comparison with the original may maximize the 
emphasis on the feelings and emotions of the narrator and characters of the story, with the effect of heightening the vividness of direct speech (Longacre 1996: 4042; Leech and Short 2007: 148).

This increased enunciation of the narrator and characters via translation may not only lead to an increased involvement on their part in the story events, but also leads to more 'emotional and ethical involvement' (Toolan 2016: 38) on the part of the target reader compared to the source. Translating the indefinite article "a" into "my" in Jane's utterance "yet it marked with change one single hour of a monotonous life" (see Example 7) not only projects her in the utterance, but also triggers a reaction on the part of the target reader with her personal feelings and emotions in the situation. If we assume that a literary text allows for the transformation of material into real feelings and psychological experiences for its readers(Harding 2014: 69) and that particularities of the literary language can create a feeling of immersion in text (Toolan 2016: 37), the trend of shift in this study may help achieve this stylistic effect of the original in the translated text (Boase-Beier 2014). The story of Jane Eyre as a bildungsroman increasingly engages the reader psychologically and mentally with its protagonist's journey of self-realization. The reader is expected to be an accomplice in her story and actively feels and changes along with her character. A shift to a more engaged narrator and an involved reader here may emphasize this stylistic characteristic of the original in the translated text. This may however suggest a shift in the psychological point of view adopted in the first four chapters of the story where Jane's presentation of herself is always described as distanced and modest (Bloom 2007: 19).

\subsection{Narratorial subjectivity}

The story of Jane Eyre employs an internal narration mode that allows the reader to experience the story events through the eyes and ears of the main narrator (see Fowler 1989: 89-93; Fowler 1996: 170-172). This narration mode is often described as being limited to the main narrators' personal evaluation and subjective perception of the story events. The increased engagement on the part of Jane Eyre, the main narrator of the story, may also suggest an increased level of narratorial subjectivity compared to the original.The translator's addition of "on me" in Jane's utterance "O aunt! Have pity on me" (Chapter 2)and "over our heads" in her utterance "These words fell over our heads like the knell of doom" (Chapter 7), which do not exist in the original, signals how directly she is involved and can only increase her subjective reporting of the events.

\subsection{Explicitness and cohesiveness}

Table (2) manifests that 219 shifts (about $70 \%$ of total shift)are brought about by lexical additions, whereas 67 shifts (about $21.4 \%$ of total shift) by lexical substitutions and 27 shifts (about $8.6 \%$ of total shift) by changing voice. This shows that there is a tendency to add person deixis via explicitation more than lexical substitution and voice switch. Most cases of the explicitations (such as the insertion of the introductory reporting clause "He said to her" or the phrase "on 
me" in "O aunt! Have pity on me")can be looked at as traces of the translator's attempts to interpret the original text and make it more "cohesive" to the target reader (Blum-Kulka 2000). They may reflect the translators' realization of "their role as intercultural and literary mediators" (Saldanha 2008:32) or at least their avoidance of leaving any potential "ambiguity" (Pápai 2004) and taking any possible "communicative risk" in the translated text (Pym 2005).

The person deictic items added via translation can most probably be inferred from the context. What brought them in other words is the verbalization of information which, if it were not verbalized, the target reader would often be able to infer from the available context(see Becher 2010: 2; Younis 2017: 29). The trend of shift here can therefore be taken as a form of amplification from the implicit to the explicit level that can be taken as an indication of the presence of explicitation in the Arabic translated texts (Klaudy 2009: 104). This may also be taken as a supporting evidence of Blum-Kulka's (2000) hypothesis of explicitation: translations are more explicit than their originals. Based on the textual analysis, this explicitation trend seems to be related to the literary translator's "preference for clarity"(Munday 2016: 184).

Whether these explicitations that brought about new person deixis are a deliberate or non-deliberate translating act, one may find some justifications for them especially in literary translation (Eco 2008: 30-39). A literary translation may for example be required to be faithful to the original, but surely not literal. A literary translator may sometimes sacrifice the literal meaning of single sentences to preserve the deep story or global sense of the entire novel (Eco 2008: 39). "The complexity of many literary messages means that literary translators are conventionally allowed a wide range of text transformation options", which may often be constrained by the translator's tendency to keep balance between loyalty to the original work and effectiveness of the translated text (Jones 2009: 154, see Yousef 2012: 54), or balance between fidelity and fluency (Wittman 2013: 439).

\section{Conclusion}

The Arabic translations do not seem to shift deictic center, nor do they tend to omit person deixis from the original. They more likely tend to explicitate the deictic knowledge implicit in the original and emphasize the role of both narrator and speaking characters in the translated narrative. The need to explicitate the original, probably to keep it communicable to the target reader, seems to be an unavoidable priority that intentionally or unintentionally brings about more anchor points or greater focalization in translation. If translation is indeed "acrosscultural event" or "an act of communication across cultural barriers' (SnellHornby 1995: 47), where a literary translator fights to maintain the deep sense of the original text (Eco 2008: 14), producing deictic structure identical to the original may have sounded the least of the Arabic translators' worries.

Unlike Goethals and De Wilde (2009), the shifts in deixis in this study seem to be systematic and tend to reflect certain translational behaviours or processes. Moreover, unlike the findings of Mason and Şerban (2003)which point to "distancing" the target reader, the tendency towards a greater deictic anchorage in 
the translated text can be indicative of a more emphasized and involved narrator which is most probably suggestive of a more emotionally-involved and approximated reader. Finally, it is recommended that future researches replicate the study on a larger sample of translations with also more conditioning factors being examined, such as, among others, the translator's ideologies and attitudes, the publisher policies, and time and space constraints. The study also recommends more analysis be conducted on different literary translations of the same translators to see in what ways the patterns of shift may be linked to the translator's style.

Othman Abualadas

Department of English Language and Literature

University of Jordan-Aqaba

Jordan

othmanadass48@yahoo.com 


\section{References}

Abualadas, Othman. (2015). A linguistically-oriented approach to literary translation: A comparative pragmatic study of three Arabic renditions of the English novel Wuthering Heights. Unpublished Ph.D.Thesis, University of Leeds, UK.

Abualadas, Othman. (2018). 'Translation shifts in spatial and temporal deixis: A trend towards a more subjective narrative mood in fiction translation'. Arab World English Journal for Translation and Literary Studies 2 (1): 182-196.

Al-Khawalda, Mohammad.(2002).'Ellipsis in Arabic and English'. International Journal of Arabic-English Studies, 3: 183-199.

Aziz, Yowell. (1993). 'Explicit and implicit reference in Arabic-English translation'. Babel, 39: (3): 129-150.

Badawi, El said, Michael Carter and Adrian Gully. (2016).Modern Written Arabic: A Comprehensive Grammar, $2^{\text {nd }}$ edition. London and New York: Routledge.

Baker, Mona. (2011). In Other Words: A Coursebook on Translation, $2^{\text {nd }}$ edition. London and New York: Routledge.

Baalbaki, Munir. (2006). Jane Eyre [Arabic translation]. Cairo: al-muPasasahal'arabi:yhal-hadi:thah.

Becher, Viktor. (2010). 'Abandoning the notion of translation-inherent explicitation: Against a dogma of translation studies'. Across Languages and Cultures, 11 (1): 1-28.

Black, Elizabeth. (2006). Pragmatic Stylistics. Edinburgh: Edinburgh University Press Ltd.

Bloom, Harold. (2007). Bloom's Guides: Charlotte Brontë's Jane Eyre. New York: Infobase Publishing.

Blum-Kulka, Shoshana. (2000). 'Shifts of cohesion and coherence in translation'. In Lawrence Venuti (ed.), The Translation Studies Reader,298313.London and New York: Routledge.

Boase-Beier, Jean. (2014). 'Stylistics and translation'. In Michael Burke (ed.), The Routledge Handbook of Stylistics, 393-407. London and New York: Routledge.

Bosseaux, Charlotte. (2007). How Does it Feel? Point of View in Translation: The Case of Virginia Woolf into French. Amsterdam: Rodopi.

Catford, John. (1965). A Linguistic Theory of Translation. London: Oxford University Press.

Eco, Umberto. (2008). Experiences in Translation. Trans. Alastair McEwen. Toronto: University of Toronto Press.

Emery, Peter. (2004). 'Translation, equivalence and fidelity: A pragmatic approach'. Babel, 50 (2): 143-167. 
Fawcett, Peter. (2003). Translation and Language: Linguistic Theories Explained. Manchester: St Jerome Publishing.

Fowler, Roger. (1989). Linguistics and the Novel. London and New York: Routledge.

Fowler, Roger. (1996). Linguistic Criticism, $2^{\text {nd }}$ edition. Oxford: Oxford University Press.

Goethals, Patrick and July De Wilde (2009). 'Deictic center shifts in literary translation: The Spanish translation of Nooteboom's Het VolgendeVerhaal'. Meta, 54 (4): 770-794.

Harding, Jennifer. (2014). 'Reader response criticism and stylistics'. In Michael Burke (ed.), The Routledge Handbook of Stylistics, 68-84. London and New York: Routledge.

Hassan, Bahaa-edin. (2011). Literary Translation: Aspects of Pragmatic Meaning. Cambridge: Cambridge Scholars.

Hickey, Leo. (1998). The Pragmatics of Translation. Clevedon: Multilingual Matters.

Jacobson, Karin. (2000). CliffsNotes: Brontë's Jane Eyre. New York: Hungry Minds, Inc.

Jones, Francis. (2009). 'Literary translation'. InMona Baker and Gabriela Saldanha (eds.), Routledge Encyclopaedia of Translation Studies, $2^{\text {nd }}$ edition, 152-57. London: Routledge.

Klaudy, Kinga and KrisztinaKároly. (2005). 'Implicitation in translation: Empirical evidence for operational asymmetry in translation'. Across Languages and Cultures, 6(1): 13-28.

Klaudy, Kinga. (2009). 'Explicitation'. In MonaBakerand Gabriela Saldanha (eds.), Routledge Encyclopaedia of Translation Studies, $2^{\text {nd }}$ edition,80-84. London: Routledge.

Leech, Geoffrey and Mick Short. (2007). Style in Fiction, $2^{\text {nd }}$ edition. London: Pearson Education Limited.

Levinson, Stephen. (1983). Pragmatics. Cambridge: Cambridge University Press.

Levinson, Stephen. (2006). 'Deixis'. In Laurence Horn and Gregory Ward (eds.), The Handbook of Pragmatics, 97-121.Oxford: Blackwell Publishing.

Longacre, Robert. (1996). The Grammar of Discourse, $2^{\text {nd }}$ edition. London and New York: Plenum Press.

Mason, Ian and Adriana Şerban. (2003). 'Deixis as an interactive feature in literary translations from Romanian into English'. Target, 15 (2): 269-294.

Morini, Massimiliano. (2013). The Pragmatic Translator: An Integral Theory of Translation. London: Bloomsbury.

Murad, Helmi. (1998). Charlotte Brontë: Jane Eyre. Beirut: Dar al- ${ }^{c}$ ilm li-alMalayeen.

Munday, Jeremy. (2008). Style and Ideology in Translation. New York and London: Routledge.

Munday, Jeremy. (2016). Introducing Translation Studies: Theories and Applications, $4^{\text {th }}$ edition. London and New York: Routledge. 
Napierkowski, Marie. (1998). Novels for Students. Farmington Hills: Gale Research.

Pápai, Vilma. (2004). 'Explicitation: A universal of translated text?' InAnna Mauranen and PekkaKujamäki (eds.), Translation Universals: Do They Exist? 143-164. Amsterdam and Philadelphia: John Benjamins.

Pym, Anthony. (2005). 'Explaining explicitation'. In Krisztina Károly and ÁgotaFóris (eds.), New Trends in Translation Studies: In Honour of Kinga Klaudy, 29-45. Budapest: AkadémiaiKiadó.

Richardson, Bill. (1998). 'Deictic features and the translator'. In Leo Hickey (ed.), The Pragmatics of Translation, 124-142. Clevedon: Multilingual Matters.

Saldanha, Gabriela. (2008). 'Explicitation revisited: Bringing the reader into the picture'. Trans-kom, 1 (10): 20-35.

Séguinot, Candace. (1988). 'Pragmatics and the explicitation hypothesis'. TTR: Traduction, Terminologie, Rédaction, 1 (2): 106-113.

Şerban, Adriana. (2013). 'Linguistic approaches in translation studies'. In Carmen Millán and Francesca Bartrina (eds.), The Routledge Handbook of Translation Studies, 213-227. London and New York: Routledge.

Simpson, Paul. (2004). Stylistics: A Resource Book for Students. London and New York: Routledge.

Simpson, Paul. (2005). Language, Ideology and Point of View. London and New York: Routledge.

Snell-Hornby, Mary. (1995). Translation Studies: An Integrated Approach. Amsterdam and Philadelphia: John Benjamins.

Stockwell, Peter. (2002). Cognitive Poetics: An Introduction. London and New York: Routledge.

Toolan, Michael. (2016). Making Sense of Narrative Text Situation, Repetition, and Picturing in the Reading of Short Stories. London and New York: Routledge.

Toury, Gideon. (2012). Descriptive Translation Studies and Beyond, revised edition. Amsterdam and Philadelphia: John Benjamins.

Uspensky, Boris. (1973). A Poetics of Composition. Berkeley and Los Angeles: University of California Press.

Vinay, Jean-Paul and Jean Darbelnet. (1995). Comparative Stylistics of French and English: A Methodology for Translation. Amsterdam and Philadelphia: John Benjamins.

Wittman, Emily. (2013). 'Literary narrative prose and translation studies'. In Carmen Millán and Francesca Bartrina (eds.), The Routledge Handbook of Translation Studies, 438-450. London and New York: Routledge.

Younis, Inas. (2017). 'The translation of the myth in Crucifixion in Kamel Hussein's Qaryah Zálima: A relevance approach'. International Journal of Arabic-English Studies, 17: 29-46.

Yousef, Tawfiq. (2012). 'Literary translation: Old and new challenges'. International Journal of Arabic-English Studies, 13: 49-64. 